\title{
Study on Construction Cost of Construction Projects
}

\author{
Hui Li \\ Audit Department of Tianjin Polytechnic University \\ E-mail: lihui650122@sina.com
}

\begin{abstract}
China is a country which has the largest investment amount in engineering construction in the world and which has the most construction projects. It is a significant subject for the extensive engineering managers to have effective engineering cost management in construction project management and to reasonably determine and control construction cost on the condition of ensuring construction quality and time limit.

On the basis of the status quo of losing control in Chinese construction investment and of separation of technique and economy in engineering, and guided by basic theories of construction cost control, the author discusses control methods and application of construction cost, sets forth existing issues in construction cost control and influences of these issues on determination and control of construction cost, puts forward that construction cost control should reflect cost control of the entire construction process at the earlier stage of construction, and then introduces some procedures and methods of applying value project cost control at all stages of construction projects.
\end{abstract}

Keywords: Construction cost, Cost control, Project

\section{Significance of the study}

The existing construction cost management system in China was formulated in 1950s, and improved in 1980s. Traditional construction cost managerial approach was one method brought in from the former Soviet Union based on unified quota of the country. It is characterized by the managerial approach of construction cost in the planned economy, which determines that it cannot adapt to requirements of the current market economy.

Traditional construction cost managerial approach in China mainly includes two aspects, namely, determination approach of construction cost and control approach of construction cost. The traditional determination approach of construction cost mainly applied mechanically national or local unified quantity quota to determine the cost of a construction project. Although this approach has undergone reform of over 20 years, until now, influences of planned economy management mode have still been in existence in many regions. Control approach of our traditional construction cost is mainly to control settlement and alteration of construction cost, which is merely an approach to settle accounts after the event, and which cannot satisfy the purpose of saving resources and improving work. In recent years, requirements of developed countries on project investment have been to plan to control in advance and to control in the middle of an event, whose effects have proved to be effective. An actually scientific approach should be that construction cost control approach beforehand and after the event can eliminate or diminish labour in vain or poor efficiency and unnecessary resource degradation and methods applied in implementation of construction projects before or after the event.

Considering the above situation, the academic circles put forward concept of cost management and control of the overall process as early as 1980s. They began to attach importance to prophase management of construction projects and take the initiative to conduct cost management. Afterwards, on July 1, 2003, implementation of $<<$ Cost Estimate Norm for Bill of Quantity of Construction Works $>>$ symbolized that cost estimate of China had entered a brand-new era that complied with development rules of market economy. From then on, concepts and approaches of Chinese cost management were really integrated with the international society.

Losing control of construction project investment is a universal phenomenon in fixed investment field in China. A construction project consumes quite a lot of manpower, materials and machines, with large investment, long construction cycle, and strong synthesis, so it is related with economic interests of all construction parties and means a lot to national economy. Currently, in the field of Chinese project construction, there exists the status quo of separation of technique and economy. Most of engineers and technicians tend to regard construction cost as duty of financing and 
preliminary budget personnel, and mistakenly believe that it has nothing to do with themselves. In the process of carrying out a project, they usually only focus on quality control and progress control, while they ignore control over investment in construction projects. If technicians ignore construction cost, and those who are in charge of construction cost have no knowledge in relevant technical construction connected with construction cost, then it is difficult for them to reasonably confirm and effectively control construction cost. Construction supervision investment control refers to managerial activities at the whole implementation state of the project, which attempts to guarantee realization of project investment targets with the premise of satisfying quality and progress. Investment targets are set at different stages with further progress of construction practice, and construction cost control runs through the entire process of project construction, but it should give prominence to the key points. Obviously, the key of construction cost control lies in investment decision-making and design stage before the construction, while after the investment decision is made, the key lies in the design. Life cycle of construction project includes construction cost and recurrent expenditure after the construction project is put into service, and discard and removal costs etc after usage period of the project. According to analysis of some western countries, usually design cost only amounts to less than $1 \%$ of life cycle of construction project. However, it is the cost of less than $1 \%$ that accounts for more than $75 \%$ of influences on construction cost. It is therefore obvious that, design quality is vital to benefits of the entire project construction.

For a long time, construction cost control of the preliminary engineering of project construction has been ignored in China, while the primary energy of controlling construction cost has been focused upon auditing working drawing estimate, settling construction cost and settling itemized account during construction. Although this has its effect, after all, this had no difference from taking precautions after suffering a loss and getting half the result with twice the efforts. In order to effectively control construction cost, the emphasis of control should be firmly transferred to preliminary construction stage. At present, we should take all pains to grasp this significant stage so as to achieve maximum results with little effort.

This article aims to analyze existing issues in cost control of the entire construction period through study on theoretical methods and practice of construction cost management. Especially, issues in cost control in the earlier period of construction deserve our research, so that we can explore corresponding reform measures to offer some references for construction project cost control.

The situation of a construction project in which budgetary estimate exceeds estimation, budget exceeds budgetary estimate, and settlement exceeds budget, is a universal phenomenon in investment in fixed assets in China. Construction cost which is out of control adds to investment pressure, increases construction cost, reduces investment profit, affects investment decision-making, and, to a great extent, wastes the national finance, so it is likely to result in corruption or offence. Since the middle of 1950 s, on the basis of summarizing practical experiences of fundamental construction battle line for several decades, we have conducted a series of reforms in construction field. Especially since May 1988, we have gradually implemented the system of construction supervision all over the country, which has had some positive effects upon reversing the phenomenon of losing control of a construction project in the implementation period. However, because that system is still in its starting stage, there hasn't appeared a large batch of professional and socialized supervision teams. In addition, in projects in which construction supervision is carried out, there exist general phenomena, such as "emphasis on quality control at the construction stage and neglect of investment control", and "emphasis on technical aspects of supervision and neglect of economic aspects of supervision". In reality, rights of supervision tend to be confined to management of technical aspects, while management of economic aspects is firmly in control of proprietors. Meanwhile, lagging behind of existing construction cost management system is the primary cause for losing control of construction cost. Therefore, as a whole, the phenomenon of losing control over construction project cost is still quite serious, so it is necessary to conduct further study and make further analysis on major factors of current construction cost management and factors at all stages of a construction project that affect construction cost.

\section{Primary study content}

Aiming at the subject of "control of whole-process of construction project cost", and based on lots of literature reviews about determination and control of construction project cost both at home and abroad, the author of this paper has collected extensively some relevant provincial and city reports and data after investigation. Afterwards, the author conducts the following work.

1) To analyze formulation of construction project investment and to find out primary reasons for losing control over construction cost at all stages of a construction project.

2) To study and analyze status quo and existing issues of current construction cost management, and study influences of these issues upon determination and control of a construction cost.

3) To put forward effective approaches and methods as well application of value engineering of a construction project from its decision-making stage, design stage, construction stage to the final acceptance of construction stage. 
4) To make clear significance, necessity and feasibility of cost control of a construction project so as to provide recommendations for improvement of construction cost management in China.

\subsection{Construction cost control theory and management mode}

According to the new cost control theory, cost engineers are "professional persons who undertake cost estimate, cost control, marketing planning and scientific management”. Fields undertaken by cost engineers include such aspects as project management, project planning, progress management and profitability analysis etc of a project construction and its production process. Cost engineers offer service for control over life cycle expenditure, property facilities and production \& manufacture of a construction project with their management technique with an overall cost.

\subsection{Current construction cost management model and theories in China}

\subsubsection{Direct regulation and control of the government}

Considering development process of quota, it can be discovered that quota has come into being, developed and become mature gradually with development of planned economy after foundation of PRC. Since China has carried out centralized management model of investment system for a long time, the government is not only a maker of macropolicy, but a participant of micro-project construction. Therefore, a unified quota with dense colour of planned economy is able to provide powerful methods and means for the government to carry out macro-investment regulation and control and micro-construction project management.

\subsubsection{Valuation basis for current construction cost}

Basic materials for calculation of construction cost usually include construction cost quota, construction cost expense quota, cost index, basic unit price, quantities calculation rule and relevant economic rules and policies issued by competent departments of the government, etc. It includes index of estimate (budgetary estimate index), budgetary estimate quota, budgetary quota (comprehensive budgetary quota), expense quota (standard), labor quota, working-day norm, materials, budgetary price of facilities, direct price index of a project, material price index and cost index. And also included is valuation criterion of consumption quota and list of items in recent two years.

\subsubsection{Valuation model of current construction cost}

Valuation model is a basic aspect of construction cost management. Construction cost management is a governmental behavior, while valuation model is a means for a country to manage and control construction cost. There are two construction valuation models at present in China, namely, valuation model according to quota and one according to bill of quantities.

\subsubsection{Valuation model according to quota}

Valuation model according to quota is an effective model adopted during the transition period from planned economy to market economy. Determination of construction cost through valuation model according to quota prevents overrated valuation and standards and prices pressed down to some extent, because budgetary quota standardizes rate of consumption and a variety of documents stipulate manpower, materials, unit price of machines and all sorts of service fee norms, which reflects normativity, unitarity and rationality of construction cost. However, it has an inhibited effect upon market competition, and is not favorable for a construction enterprise to improve its technique, strengthen its management and enhance its labor efficiency and market competition.

\subsubsection{Valuation model according to bill of quantities}

Valuation model according to bill of quantities is a construction cost determination model proposed recently. In this model, the government merely unifies project code, project name, unit of measurement and measurement rule of quantities. Each construction enterprise has its self-determination to quote a price according to its own situation in a tender offer, and price of building products is formed thereby in the process of bidding.

\subsection{Cost control in the process of implementation}

For a long time, technique and economy has been separated in the field of project construction. Restrained by the planned economy, there lacks the economic concept in the minds of our engineers and technicians, because they regard reduction of construction cost as a duty of financial personnel which has nothing to do with themselves. However, the primary responsibility of financial and preliminary budget personnel is to act in accordance with financial system. Usually, they are not familiar with construction technique, and know little or even nothing about changes of various relations in project design, construction content and implementation of construction. Under such a circumstance, they have no choice but to mechanically work out or audit the expenditure from a financial perspective, which results in mutual separation of technique and economy. They just do what they do, which negatively reflects price of quantities of a project that has been completed, so it is difficult to control construction cost rationally and effectively. 


\subsection{Control of cost in the process of construction}

Implementation stage of a construction project is a stage which requires the most assets in the whole process of a project construction, and is also a vital stage for pecuniary resources to transform into building entities. Cost control at the implementation stage refers to confine construction cost within a scheduled control scope through a scientific cost control theory and method on the condition of ensuring project quality and time limit. The process of generation of a building entity is inreversible, so if effective automatic control and precontrol cannot be conducted over construction cost, then economic loss might be caused that cannot be made up for.

\subsection{Analysis of major factors that affect construction cost at the stage of implementation}

Implementation stage of a project refers to the period from completion of construction documents design and examination and submission to the construction party to the final completion acceptance of the project and until it is put into use. According to the basic operation procedure of the implementation stage of a construction project, formation of a construction cost has to undergo such major aspects as bidding, contract signing and management, joint auditing of a shop drawing, investigation of a construction management plan, material management and completion settlement, etc. All these aspects affect construction cost settlement to different degrees. In that process, after evolving from budgetary price, price for successful bidding, refurbishing cost for a contract, the construction cost is finally determined in the form of settlement price for project completion. Factors affecting construction cost are various, but from the perspective of analysis of cost formation, there are primarily the following reasons.

1) Influences of a project bidding. Bidding can determine price for successful bidding, while contract price is determined on the basis of price for successful bidding. If something goes wrong with bidding, then it might result in distortion of the price for bidding, and it is impossible to provide accurate and reliable foundation for cost control, and even result in losing control over the cost.

2) Influences of contract signing and management. Determination of a contract price further makes precise target of cost control, and an initial draft of a contract term provides correct foundation and principles for cost control. After signing of a contract, contract items are regarded as foundation, which will have strict contract control over design changes at the construction stage, project measurement, payment of a construction debt, and construction compensation, etc, and which will ensure realization of a control target. Therefore, losing control over signing and management of a contract will necessarily result in losing control over construction cost.

3) Influences of examination of construction management plan. Construction management plan is one of important foundations for determine a project bidding price and contract price. In the process of construction, adjustment of a contract price should also be determined according to construction management plan, because quality of construction management plan will directly affect quality and progress of a project. Therefore, losing control over examination of construction management plan will bring extremely unfavorable influences upon control over construction cost.

4) Influences of material management. On one hand, material price is an important component of bidding price and contract price. On the other hand, material expense accounts for a large proportion in construction cost, because price of materials determine construction cost. Therefore, losing control over material management will necessarily result in losing control over construction cost.

5) Influences of settlement, examination and verification of a project completion. Settlement, examination and verification is the final stage of a construction cost control at the implementation stage. A strict and meticulous settlement, examination and verification can ensure accuracy and authenticity of settlement cost of a project.

According to previous analysis, we believe that all aspects of cost control can have effect upon formation of construction cost, among which bidding of a project, contract signing and management, examination of a construction management plan and management of materials all have decisive effects upon formation of construction cost, and are vital aspects in cost construction at the implementation stage of a project, so neglect of these four aspects is a direct cause for losing control over construction cost.

In this paper, the author summarizes relevant issues in construction cost control at the decision-making stage of a construction project, at the design stage and construction stage, and puts forward principles or resolutions for handing such issues. Especially, as a method of combination of technique and economics, application of value engineering is elaborated at all stages, so that construction cost gets effective controlled. This paper cannot conclude all such issues existing, and also resolutions to resolve these issues cannot cover and contain everything, but with development of construction, new issues and new trains of thought will continue to emerge.

\section{References}

Aminan Fayek. (1998). Competitive Bidding Strategy Model and Software System for Bid Preparation. Jounal of Construction Engineering and Management.

Chen, Jianguo. (2001). Project Measurement and cost management. Shanghai: Tongji University Press. 
Don R.Hansen \& Maryanne M. Mowen. (2005). Cost Management: Accounting and Control.

Dong, Shibo. (2003). Status Quo of Construction Cost Management Theory and Its Developmental Trend. Construction Cost Management, (5).

Feng, Jingchun. (2000). Study on Counter Measures of Project Cost Management. Technical and Economic Development, (6).

George J.Ritz. (1993). Total Construction Project Management.

Gou, Zhiyuan. (2002). Thought on Integrated Control Approach of Construction Cost Management. Construction Cost Management, (6).

Hao, Jianxin. (2002). American Construction Cost Management. Tianjin: Nankai University Press, 1, 51.

Hu, Jianming. (2002). Discussion on Construction Cost Estimation Consultant Participating in Whole Course of Cost Management. Construction Cost Management, (5).

Hu, Zhifeng. (2000). Overall Process Control on Construction Projects. Coal Enterprise Management, (7).

Huang, Yonggen. (2004). Value Engineering and Its Application in Construction Cost Control. Construction Economics, (8).

Ivor H Seeley. (1996). Building economics (fourth edition). Macmillan Press LTD.

James A.Bent \& Kenneth King Humphreys. (1996). Effective Project Management through Applied Cost and Schedule Control, Cost Engineering.

Jan Emblemsavg. (2003). Life cycle Costing: sing Activity-based Costing and Monte Carlo Methods to Manage Future Costs and Risks. John wiley \& sons, (5).

Janice T. Dana. (1999). Standardized Quantity Recipe File for Quality and Cost Control.

John E.Schaufelberger \& Len Holm. (2001). Management of Construction Projects: A Constructor's Perspective.

John Innes, Falconer Mitchell \& Takeo Yoshikawa. (2000). Activity Costing for Engineers. Research Studies Press Ltd.

John R.Canada, William G Sullivan, Dennis 3. Kulonda \& John A.White. (2004). Capital Investment Analysis for Engineering and Management.

Li, Tinggui. (2003). Study on Cost Management Model and Countermeasures of Construction project after China's entry into the WTO. Construction Cost Management.

Liu, Guiwen \& Shen, Qiping. (2001). A Study of Value Engineering Applications in China's Construction Industry. Value Engineering, (3).

Liu, Hongqing. (2003). About overall cost control. Shanxi Architecture, (29)6.

Liu, Zhongying \& Mao, Jian. Architecture Project Quantity List Quotation. Southeast University Press, 9.

Luo, Dinglin. (1997). Determination and Control of Construction Project Cost at Home and Abroad. Beijing: Chemical Industry Press.

Ma, Guanghong \& Xu, Wei. (2003). Discussion on Application of Overall Cost Management Theory. Project Management, (4).

Ma, Guanghong \& Xu, Wei. (2003). Discussion on Application of Overall Cost Management Theory. Project Management, (4).

Norton B R \& McElligot C W. (1995). Value management in construction: a practical guide. Hampshire: Macmillan Press.

Paul J. McVety. (1997). The Menu and the Cycle of Cost Control.

Project Management Institute. (2004). A Guide to the Project Management Body of Knowledge.

Qi, Anbang. (2000). Total Cost Management for Engineering Project. Tianjin: Nankai University Press.

Qin, Aiguo. (1999). Study on Construction Cost Management. Economic Tribune, (22).

Ren, Guoqiang \& Yin, Yilin. (2003). The Feasibility Study on Life Cycle Cost Management in Terms of Paradigm Transformation. China Soft Science Magazine, (5).

Ren, Hong. (2004). Cost Planning and Control of Construction Project. China Higher Education Press.

Sidney M.Levy. (2002). Project Management in Construction.

Stephen P Robbins \& David A. Decenzo. (2002). Fundament of Management. Prentice Hall, Inc. 
Takashi Ishikawa. (1996). Analogy by Abstraction: Case Retrieval and Adaptation for Inventive Design Expert Systems. Expert Systems with Application, (4)10.

Tao, Xueming, Huang, Yunde \& Xiong, Wei. (2004). Construction Cost Valuation and Management. China Architecture \& Building Press, 2.

Wang, Ailin. (2003). Value Engineering and Its Application in Constructional Engineering. Anhui Architecture, (5).

Wang, Li \& Xu, Zihua. (2004). Comparative Study on Construction Cost Models at Home and Abroad. Architecture Economics.

Wang, Yulong. (1997). 2000 Cases on Issues of Construction Project Cost. Shanghai: Tongji University Press.

Wang, Zhenqiang. (2002). British Construction Cost Management. Tianjin: Nankai University Press.

Wang, Zhenqiang. (2002). Japanese Construction Cost Management. Tianjin: Nankai University Press, 4.

Xiang, Ke \& Luo, Feng. (2004). Cost Control of Design Stage. Sichuan Architecture, (2).

Xu, Datu. (1997). Determination and Control of Construction Cost. Beijing: China Planning Press.

Xu, Datu. (1997). Investment Control of Construction Project. Beijing: China Planning Press.

Yin, Yilin. (2001). Determination and Control of Construction Cost. Beijing: China Planning Press.

Zhang, Caijiang, Li, Kehua \& Xu, Yongmei. Review of VE Theory and Practice in China and Some Deep Thinking about its Depression. Nankai Business Review, (1).

Zhong, Guangen. (2004). Brief Discussion on Cost Control System in Projects of Commonwealth Nations.

Zuo, Jin \& Han, Hongyun. Actuality \& Amelioration of Whole Life-cycle Value-chain in Architecture. Value Engineering, (6). 